\title{
Knowledge, Attitudes And Practices Towards COVID-19 among Medical Students in International Islamic University Malaysia: An Online Cross-Sectional Study.
}

\author{
Ikhlas Solehah $\mathrm{AR}^{1}$, Muhammad Badrul NR ${ }^{1}$, Nur Najihah $\mathrm{MZ}^{1}$, Nur Syazwani $\mathrm{K}^{1}$, Muhammad Izz \\ Hilmi MY ${ }^{1}$, Hafizah $\mathrm{P}^{1}$, Hashima $\mathrm{E} \mathrm{N}^{1}$ \\ ${ }^{1}$ Department of Community Medicine, Faculty of Medicine, International Islamic University Malaysia, Kuantan, Pahang, Malaysia
}

\section{ABSTRACT}

INTRODUCTION: COVID-19 pandemic has caused a major impact to global public health including one of the high risk groups which is the medical students. This study was intended to assess knowledge, attitudes and practices (KAP) towards COVID-19 among medical students in International Islamic University Malaysia (IIUM). MATERIAL AND METHOD: An online cross-sectional study was conducted among 438 medical students of IIUM from 6th July 2020 to 9th July 2020. KAP towards COVID-19 was measured using a structured Malay and English version questionnaire consisting of 13 items on knowledge, 3 items on attitudes and 3 items on practices. RESULTS: The average correct response rate on knowledge was $85.4 \%$. Only $12.1 \%$ of the students had correct knowledge on all items, and 1 in every 4 and 5 students had misconceptions on the clinical features and transmission of COVID-19. In term of attitudes towards COVID-19, majority of the respondents believed that COVID-19 would be effectively controlled (85\%) and had faith that Malaysia could overcome the war against COVID-19 (99\%). Most of the respondents practiced good towards COVID-19 in avoiding crowded places (90\%), wearing face masks $(95 \%)$ and practicing hand hygiene (91.6\%). CONCLUSION: Although the results are positive towards KAP, only 1 in every 10 students responded correctly to all knowledge questions, and few proportions had misconceptions on the disease and did not maintain adequate practices. Policies aimed at appropriate health promotion activities may ensure empowering the medical students with adequate knowledge on all aspects of COVID-19, and practice properly following the standard operating procedure implemented by the government.

KEYWORDS: COVID-19, Knowledge, Attitudes, Practices, Medical students

\section{INTRODUCTION}

The coronavirus disease, known as COVID-19, was first detected in December 2019 when a cluster of 'viral pneumonia' cases was reported in Wuhan, China. Since then, it has rapidly spread around the globe. The disease was declared as a pandemic on 11th March 2020 by the World Health Organization. ${ }^{1}$ It is a highly

Corresponding author:

Dr. Ikhlas Solehah Abd Rahim

Department of Community Medicine,

Kulliyyah of Medicine

International Islamic University Malaysia

25200 Kuantan, Pahang, Malaysia.

Tel No : +60199209307

Email : ikhlas1396@gmail.com communicable disease, caused by a novel coronavirus, the Severe Acute Respiratory Syndrome Coronavirus 2 (SARS-CoV-2). According to WHO, the main routes of transmission are respiratory droplets, direct contact with infected persons, or contact with contaminated objects and surfaces, with a mean incubation period of 5-6 days, lasting up to 14 days. ${ }^{2}$ Major symptoms of this disease include fever, dry cough, fatigue, myalgia, and dyspnea. ${ }^{3}$ Severe illnesses may be manifested by Acute Respiratory Distress Syndrome (ARDS), septic shock, metabolic acidosis, bleeding and coagulation disorders. To date, there are still no available antiviral or vaccine clinically approved against COVID-19, though some drugs are currently undergoing clinical trial. ${ }^{4}$ 
In Malaysia, the first wave of COVID-19 infection started on 24th January 2020, with a total of 22 cases. The second wave of infection begun on 27 th February 2020 and the new cases are still occurring. ${ }^{5}$ To date, Malaysia has a total of 10,919 confirmed cases, with a recovery rate of $90.07 \%$ and fatality rate of $1.39 \% .{ }^{6}$ The recovery rate in Malaysia is among the highest in the ASEAN countries. ${ }^{7}$ The Malaysian government is currently imposing the Recovery Movement Control Order (RMCO), which has been effective starting from 10th June 2020 and will be ending on 31st December 2020. Conditions under the RMCO include interstate travel, re-opening of morning and night markets and the resumption of almost all social, religious, business, and educational activities under the strict standard of operation. ${ }^{5}$ People's adherences to the control measures are influenced by their knowledge, attitudes and practices (KAP) towards the disease. ${ }^{8}$ Lessons learned from other epidemic indicated that people's knowledge and attitudes are associated with the levels of panic emotions which may complicate the measures to prevent the further spread of disease. ${ }^{9}$ KAP studies provide initial information to determine the type of intervention required to change misconception about the virus. ${ }^{10}$

During RMCO, students undergoing their studies in public universities has been started going back to their respective universities in stages, starting from July 2020 until October 2020. Among the first returning groups are the medical students, specifically for their requirement to undergo clinical rotations. ${ }^{11}$ As they return, they may have the risk to be in contact with infected patients in their clinical sessions at the hospital. ${ }^{12}$ Besides, in view of their future role as medical practioners, it is important that the medical students should have adequate knowledge to counter the misinformation regarding COVID-19, and to educate the public. ${ }^{13}$ To the best of our knowledge, only one study has been published on KAP towards COVID-19 among general population in Malaysia, ${ }^{10}$ and no research has yet been carried out among medical students. This study aims to measure the level of KAP towards COVID-19 among medical students of International Islamic University Malaysia (IIUM).

\section{MATERIALS AND METHODS}

\section{Study design and setting}

An online cross sectional study was carried out among medical students in IIUM Kuantan campus, Pahang from 6th to 9th July 2020. IIUM is a public university in Malaysia consisting of several campuses with different specialisation situated across the states of Malaysia in Gombak, Kuantan, Kuala Lumpur, Gambang and Pagoh.

\section{Study population and sample size}

The study population included undergraduate medical students from year 1 to year 5, currently studying in IIUM Kuantan Campus. The exclusion criteria included 23 medical students who conducted the survey and medical students who were not living in Malaysia during the data collection period. We considered proportions of all parameters of KAP towards COVID-19 in Malaysia $^{10}, \pm 5 \%$ margin of error and confidence interval of $95 \%$ for sample size calculation. Sample size was calculated using the single proportion formula and the highest sample size of 384 was obtained using the prevalence of wearing face masks. Considering 50\% of non-response rate, the adjusted sample size was 768 . The universal sampling method was employed as the required sample size exceeded the number of our study population of 709 . Out of 709, 438 respondents participated in the study making the response rate of $62 \%$.

\section{Measures}

The knowledge on COVID-19 was measured by using a 13-items questionnaire. ${ }^{10}$ The questions were used to assess the respondents' knowledge on clinical presentation of COVID-19 (questions 1-4), transmission of the virus (questions 5-8) and prevention and control of COVID-19 (questions 9-13). Participants were given the option of "true", "false" or "I'm not sure" for each of the items and they will be given 1 point for every correct answer and 0 point for wrong answer or "not sure". Items numbered 1, 2, 3, 4, $7,9,11,12,13$ were considered to be correct if 
answered "true" and incorrect if answered "false" and "not sure". Meanwhile, items 5, 6, 8, 10 was considered to be correct if answered "false", and incorrect if "true" and "not sure". A composite score was computed ranging from 0-13, a higher score indicated a better knowledge about COVID-19. The Cronbach alpha for the scale was 0.66 .

Attitudes towards COVID-19 was measured by 3 questions. It was assessed by the level of respondents' agreement on whether COVID-19 would be successfully controlled or not, their confidence in winning the battle against COVID-19, and whether the government of Malaysia was handling the COVID-19 very well or otherwise. The levels of agreements are agree, disagree or I'm not sure. The questions on confidence towards Malaysia government in winning the battle against COVID-19 was categorized into yes or no.

Respondents' practices towards COVID-19 were measured by yes or no on three practices implemented during Movement Control Order (MCO). These included whether they had avoided going to crowded places such as weddings, wore a face mask when leaving home, and whether they practiced proper hand hygiene.

Year of study was categorized into year 1 to year 5 and respondents' age was measured in years. Gender was dichotomized as male or female, nationality as Malaysian and non-Malaysian, and marital status as married and unmarried. Ethnicity was grouped into Malay, Chinese, Indian and others including Melanau and Iranun people. The region was categorized into northern region (Perlis, Penang, Kedah and Perak), central region (Selangor, Kuala Lumpur and Putrajaya), southern region (Negeri Sembilan, Melaka and Johor), eastern region (Terengganu, Pahang and Kelantan), and Labuan, Sabah and Sarawak. Respondents' household income was measured by parents' monthly income, and was categorized into T20 (above RM 8319), M40 (RM 3856 - RM 8318) and B40 (below RM 3855). ${ }^{14}$

\section{Data collection}

As it was not feasible to conduct a systematic face to face data collection during the RMCO period, we opted to use an online survey using Google Form. A standardised general description pertaining to the survey was given through a text messaging application. Respondents who agreed to participate in the study clicked on the link of the questionnaire. Data was collected by a structured questionnaire, both the English and Malay version, which was adapted and used for the national study on the public KAP towards COVID-19 in Malaysia. ${ }^{10}$ The questionnaire consisted of four parts including socio-demographic profile, knowledge about COVID-19, attitudes toward COVID-19, and practices relevant to COVID-19.

\section{Statistical analysis}

Frequencies, percentages, mean, standard deviation (SD), median and interquartile range (IQR) were used to explore the distribution of sociodemographic characteristics of respondents, and to measure the level of KAP towards COVID-19. Independent sample ttests, ANOVA (analysis of variance) and chi-square test (Fisher's exact test) were used to analyse the relationship between the KAP towards COVID-19 and the sociodemographic characteristics of the respondents. Pearson's correlation assessed the relationship between knowledge versus practices and knowledge versus attitudes.

\section{Ethical approval}

The study was approved by the Kulliyyah of Medicine Research Committee (KRC) and IIUM Research Ethic Committee (IREC), with IREC ID Number of 557. A general description including an informed consent form was obtained by a text messaging application.

\section{RESULTS}

\section{Respondents' demographic and economic profile}

A total of 438 medical students of IIUM participated in this study. Out of the total, the average age was 22.9 years (SD 1.7; range $=19-27), 300(68.5 \%)$ were women, and 165 (37.3\%) resided in Eastern Malaysia. More than one-third of the respondents were from T20 category of household with the median monthly household income of RM 6,000 [Table I]. 
Table I. Demographic and economic profile of respondents (percentage unless otherwise reported) $(\mathrm{N}=438)$

\begin{tabular}{lll}
\hline Characteristics & & Number (\%) \\
\hline Mean age (SD) & & $22.9(1.7)$ \\
Gender & Male & $138(31.5)$ \\
Year of study & Female & $300(68.5)$ \\
& Year 1 & $62(14.2)$ \\
& Year 2 & $68(15.5)$ \\
& Year 3 & $108(24.7)$ \\
Year 4 & $93(21.2)$ \\
Race & Year 5 & $107(24.4)$ \\
Region & Malay & $434(99.1)$ \\
& Non-Malay & $4(0.9)$ \\
& Central & $113(25.8)$ \\
& Northern & $72(16.4)$ \\
& Southern & $76(17.4)$ \\
& Eastern & $165(37.7)$ \\
Marital status & Labuan/Sabah/ & $11(2.5)$ \\
& Sarawak & \\
Household income & Married & $9(2.1)$ \\
& Non-married & $429(97.9)$ \\
& B40 & $127(29.0)$ \\
Median household & M40 & $143(32.6)$ \\
income (IQR) & T20 & $162(37.0)$ \\
& & RM6000 \\
& & RM7000) \\
\hline
\end{tabular}

\section{Respondents' knowledge on COVID-19}

The average knowledge score of respondents was 11.1 (SD 1.4) with the overall correct response rate for the knowledge questionnaire was $85.4 \%$. Approximately $71 \%$ of respondents had $\geq 11$ correct knowledge and $12 \%$ had correct knowledge on all 13 items [Figure 1].

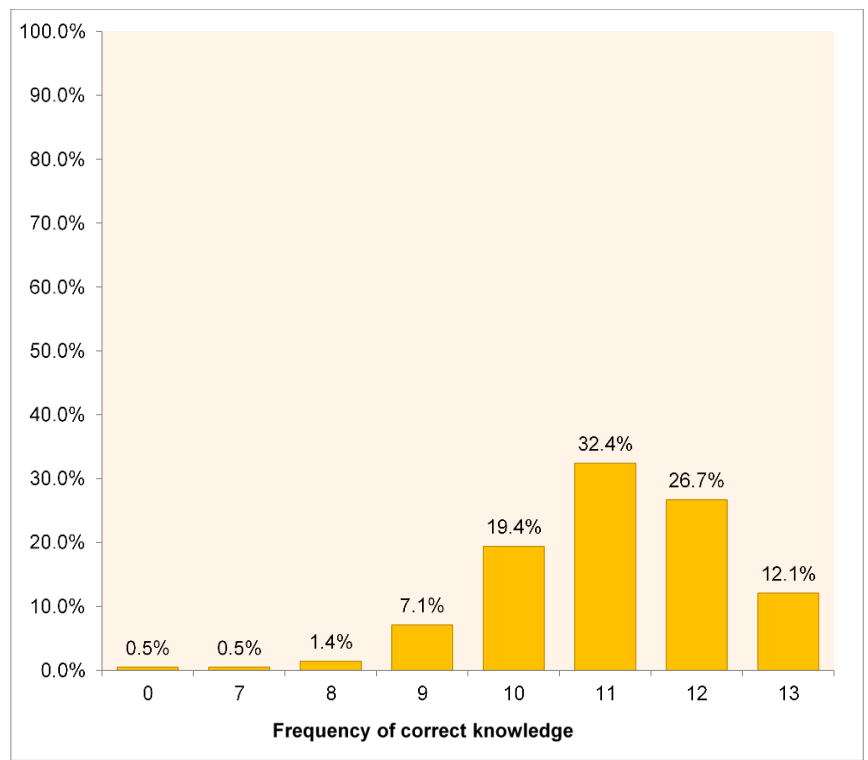

Figure 1. Respondents' frequency of correct knowledge on COVID-19
Table II. Respondents' knowledge of COVID-19 (N = 438).

\begin{tabular}{|c|c|c|}
\hline Question & Correct & Incorrect \\
\hline $\begin{array}{l}\text { 1. The main clinical symptoms of } \\
\text { COVID-19 are fever, fatigue, dry } \\
\text { cough, and body aches. }\end{array}$ & $346(79.0 \%)$ & $92(21.0 \%)$ \\
\hline $\begin{array}{l}\text { 2. Unlike the common cold, stuffy } \\
\text { nose, runny nose, and sneezing are } \\
\text { less common in persons infected } \\
\text { with the COVID-19 virus. }\end{array}$ & $261(59.6 \%)$ & $177(40.4 \%)$ \\
\hline $\begin{array}{l}\text { 3. There currently is no effective cure } \\
\text { for COVID-19, but early } \\
\text { symptomatic and supportive } \\
\text { treatment can help most patients } \\
\text { recover from the infection. }\end{array}$ & $426(97.3 \%)$ & $12(2.7 \%)$ \\
\hline $\begin{array}{l}\text { 4. Not all persons with COVID-2019 } \\
\text { will develop to severe cases. Only } \\
\text { those who are elderly and have } \\
\text { chronic illnesses are more likely to } \\
\text { be severe cases. }\end{array}$ & $423(96.6 \%)$ & $15(3.4 \%)$ \\
\hline $\begin{array}{l}\text { 5. Eating or touching wild animals } \\
\text { would result in the infection by the } \\
\text { COVID-19 virus. }\end{array}$ & $250(57.1 \%)$ & $188(42.9 \%)$ \\
\hline $\begin{array}{l}\text { 6. Persons with COVID-19 cannot } \\
\text { infect the virus to others if they do } \\
\text { not have a fever. }\end{array}$ & $401(91.6 \%)$ & $37(8.4 \%)$ \\
\hline $\begin{array}{l}\text { 7. The COVID-19 virus spreads via } \\
\text { respiratory droplets of infected } \\
\text { individuals. }\end{array}$ & $427(97.5 \%)$ & $11(2.5 \%)$ \\
\hline 8. The COVID-19 virus is airborne. & $200(45.7 \%)$ & $238(54.3 \%)$ \\
\hline $\begin{array}{l}\text { 9. Ordinary residents can wear face } \\
\text { masks to prevent the infection by } \\
\text { the COVID-19 virus. }\end{array}$ & $393(89.7 \%)$ & $45(10.3 \%)$ \\
\hline $\begin{array}{l}\text { 10. It is not necessary for children and } \\
\text { young adults to take measures to } \\
\text { prevent the infection by the } \\
\text { COVID-19 virus. }\end{array}$ & $421(96.1 \%)$ & $17(3.9 \%)$ \\
\hline $\begin{array}{l}\text { 11. To prevent the infection by } \\
\text { COVID-19, individuals should } \\
\text { avoid going to crowded places } \\
\text { and avoid taking public } \\
\text { transportations. }\end{array}$ & $429(97.9 \%)$ & $9(2.1 \%)$ \\
\hline $\begin{array}{l}\text { 12. Isolation and treatment of people } \\
\text { who are infected with the COVID } \\
-19 \text { virus are effective ways to } \\
\text { reduce the spread of the virus. }\end{array}$ & $434(99.1 \%)$ & $4(0.9 \%)$ \\
\hline $\begin{array}{l}\text { 13. People who have contact with } \\
\text { someone infected with the } \\
\text { COVID-19 virus should be } \\
\text { immediately isolated in a proper } \\
\text { place. In general, the isolation } \\
\text { period is } 14 \text { days. }\end{array}$ & $435(99.3 \%)$ & $3(0.7 \%)$ \\
\hline
\end{tabular}

The overall correct response rate $=(11.1 \div 13) \times 100=85.4 \%$ 
Almost all respondents (99\%) knew that people who had contact with an infected person would be isolated immediately for a duration of 14 days and that this is an effective way to prevent virus transmission (99\%). Nonetheless, there was notable uncertainty among the respondents about virus transmission. Only 46\% of respondents responded correctly when asked whether the virus was airborne and 57\% responded correctly when asked if eating and touching wild animals could lead to infection [Table II].

\section{Attitudes towards COVID-19}

Overall, $95.3 \%$ of respondents agreed that the situation of COVID-19 would be successfully controlled, Malaysia would be able to win its fight against the virus; and the Malaysian government was well prepared to deal with the health crisis.

More than $85 \%$ of the respondents believed that COVID-19 would be effectively controlled. Despite that, approximately $10 \%$ of respondents were uncertain if the virus would be controlled, and a smaller number of respondents denied that it would be effectively controlled $(1.6 \%)$. On the second attitudes question, almost all respondents $(99 \%)$ were confident that Malaysia would be able to win the battle against COVID -19. The third attitudes question whether the participant believed that the Malaysian government was coping well with the health crisis of COVID-19. A large percentage of respondents $(98.6 \%)$ agreed with this statement. Rates of disagreement and uncertainty were at $0.5 \%$ and $0.9 \%$, respectively [Figure 2].

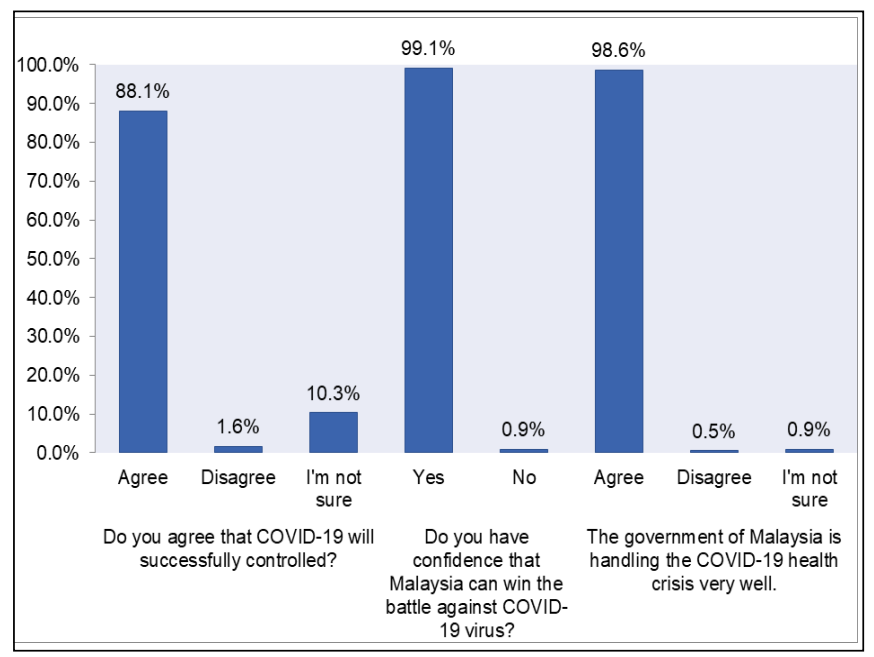

Figure 2. Respondents' attitudes towards COVID-19 ( $\mathrm{N}=438)$

\section{Practices on COVID-19}

Overall, 93.1\% of respondent showed practices correctly in terms of avoiding crowded places, wearing face masks and practicing proper hand hygiene in recent days during Movement Control Order (MCO) was implemented in Malaysia.

For the first question, nine in every 10 students stated that they had been avoiding crowded places in recent days when the MCO was implemented. Approximately $9 \%$ of the respondents did not avoid the crowded areas. The second question was about if they were wearing face masks when outside the home in recent days during the MCO. When going out in public, 97\% of the respondents reported wearing a face mask and 3\% did not wear. Finally, when questioned about hand hygiene, the majority of the respondents stated that they practiced proper hand hygiene by regularly washing their hands and using a hand sanitizer (91.6\%). Nevertheless, during the implementation of the MCO, there was still a proportion of respondents who did not practice proper hand hygiene (8.4\%) [Figure 3]

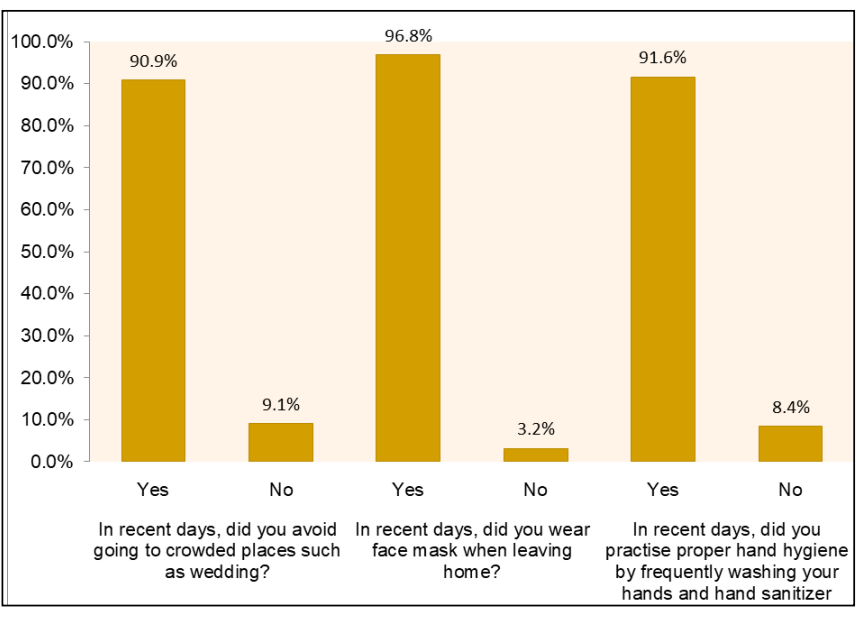

Figure 3. Respondents' practices towards COVID-19 (N=438)

\section{Association of background characteristics with the KAP towards COVID-19}

The scores of knowledge differed significantly among respondents of different years of study. The students in year 4 and year 5 had higher knowledge score compared to the students of year 1 to year 3. No significant difference was observed between the knowledge score of COVID-19 and other background characteristics [Table III]. 
Table III: Respondents' demographic and economic characteristics and knowledge score $(\mathrm{N}=438)$

\begin{tabular}{|c|c|c|c|c|}
\hline \multicolumn{2}{|l|}{ Characteristics } & \multirow{2}{*}{$\begin{array}{l}\text { Mean } \\
\text { knowledge } \\
\text { score (SD) }\end{array}$} & \multirow{2}{*}{$\begin{array}{l}t / F \\
1.968\end{array}$} & \multirow{2}{*}{$\begin{array}{l}p \\
\text { value } \\
0.050\end{array}$} \\
\hline Gender & Male & & & \\
\hline & Female & $11.2(1.2)$ & & \\
\hline \multirow[t]{2}{*}{ Year of study } & Year 1-3 & $10.9(1.5)$ & 3.397 & 0.001 \\
\hline & Year 4-5 & $11.3(1.2)$ & & \\
\hline \multirow[t]{2}{*}{ Race } & Malay & $11.1(1.4)$ & - & 0.791 \\
\hline & Non-Malay & $11.3(1.3)$ & 0.266 & \\
\hline \multirow[t]{5}{*}{ Region } & Central & $11.0(1.6)$ & 1.413 & 0.229 \\
\hline & Northern & $11.1(1.1)$ & & \\
\hline & Southern & $11.4(1.2)$ & & \\
\hline & Eastern & $10.9(1.5)$ & & \\
\hline & $\begin{array}{l}\text { Labuan/ } \\
\text { Sabah/ } \\
\text { Sarawak }\end{array}$ & $11.4(1.2)$ & & \\
\hline \multirow[t]{2}{*}{ Marital status } & Married & $11.2(1.1)$ & - & 0.733 \\
\hline & $\begin{array}{l}\text { Non- } \\
\text { married }\end{array}$ & $11.1(1.4)$ & 0.341 & \\
\hline \multirow{3}{*}{$\begin{array}{l}\text { Household } \\
\text { Income }\end{array}$} & $\mathrm{T} 20$ & $11.0(1.5)$ & 0.676 & 0.509 \\
\hline & M40 & $11.1(1.6)$ & & \\
\hline & B40 & $11.2(1.0)$ & & \\
\hline
\end{tabular}

Students who were unsure that the government of Malaysia is handling the COVID-19 health crisis very well had significantly lower knowledge score than those who agreed and disagreed. There was no significant association of other background variables with the attitudes towards COVID-19 [Table IV]. Knowledge score is positively associated with attitudes towards COVID-19 ( $\mathrm{r}=0.104, \mathrm{p}=0.030)$.

The practices in avoiding going to the crowded places during MCO are significantly higher $(p=0.011)$ in unmarried students $(91.4 \%)$ compared to married students $(66.7 \%)$. There was no significant association between the background characteristics, and avoiding crowded places, wearing face masks and practicing hand hugiene. The knowledge scores of students who wore and did not wear masks when leaving the house were 11.1 and 11.2, respectively [Data not shown].

\section{DISCUSSION}

This online survey revealed that medical students of IIUM have an acceptable level of knowledge, positive attitude towards the government in overcoming the COVID-19 pandemic and good practices during the weeks of $\mathrm{MCO}$, with the few proportions had misconceptions of the disease and did not maintain the proper practices.

\section{Knowledge of COVID-19}

Results reveals that the average knowledge score was $11.1 \pm 1.4$ with an overall correct rate of $85 \%$, which is in line with the Iranian medical students with the average correct answer on knowledge was $87 \% .^{12}$ However, this level of knowledge was lower than that demonstrated among medical students of nine medical schools in Uganda $(90 \%)^{13}$ and one medical school in India. ${ }^{15}$ Meanwhile, the medical students of IIUM have higher levels of knowledge than the nursing students in Saudi Arabia $(72 \%)^{16}$, Indian health care professional and nonmedical staff $(71 \%)^{17}$ and Bangladeshi university students $(11 \%) .{ }^{18}$ However, it is difficult to precisely compare across studies due to differences in measuring instruments, cut-off values used to categorize the knowledge levels and sociocultural variety between study settings. ${ }^{19}$ Although the average rate of correct knowledge is high, only $12 \%$ of students answered correctly to all knowledge questions.

There are few misconceptions on COVID-19 transmission. Firstly, only $46 \%$ of students answered correctly on respiratory droplets transmission of the virus. Similar misconception was reported by the medical students in Indonesia. ${ }^{20}$ Consistent with the medical students in India, $1557 \%$ of students in this study perceived that eating and touching the animals could lead to infection. Although the Ministry of Health, Malaysia has been disseminating information on COVID-19 since its first detection in Malaysia, there has been a surge of many false and inaccurate information from different sources. This may have caused confusion to ascertain correct information. Consistent with the medical students in Uganda, ${ }^{13}$ our study revealed that fourth and fifth year students have significantly higher knowledge scores than the counterparts of other years. This is probably due to clerkship experiences in the medical ward and better understanding of the disease. ${ }^{13}$

\section{Attitudes towards COVID-19}

In our study, more than $90 \%$ of the students had positive attitudes towards this disease. This is similar with the attitudes of the general population in Malaysia, ${ }^{10}$ university students in China, ${ }^{21}$ and medical 
Table IV. Background characteristics and attitudes toward COVID-19 $(\mathrm{N}=438)$

\begin{tabular}{|c|c|c|c|c|c|c|c|c|c|}
\hline \multirow[b]{2}{*}{ Characteristics } & & \multicolumn{3}{|c|}{$\begin{array}{l}\text { Do you agree that COVID-19 will be } \\
\text { successfully controlled? }\end{array}$} & \multicolumn{2}{|c|}{$\begin{array}{l}\text { Do you have confidence } \\
\text { that Malaysia can win the } \\
\text { battle against the COVID } \\
-19 \text { virus? }\end{array}$} & \multicolumn{3}{|c|}{$\begin{array}{l}\text { The government of Malaysia is } \\
\text { handling the COVID-19 health crisis } \\
\text { very well. }\end{array}$} \\
\hline & & Agree & Disagree & $\begin{array}{l}\text { I'm not } \\
\text { sure }\end{array}$ & Yes & No & Agree & Disagree & $\begin{array}{l}\text { I'm not } \\
\text { sure }\end{array}$ \\
\hline \multirow[t]{2}{*}{ Gender } & Male & $126(91.3 \%)$ & $2(1.4 \%)$ & $10(7.2 \%)$ & $138(100.0 \%)$ & $0(0.0 \%)$ & $135(97.8 \%)$ & $1(0.7 \%)$ & $2(1.4 \%)$ \\
\hline & Female & $260(86.7 \%)$ & $5(1.7 \%)$ & $35(11.7 \%)$ & $296(98.7 \%)$ & $4(1.3 \%)$ & $297(99.0 \%)$ & $1(0.3 \%)$ & $2(0.7 \%)$ \\
\hline \multirow[t]{5}{*}{ Year of study } & Year 1 & $56(90.3 \%)$ & $1(1.6 \%)$ & $5(8.1 \%)$ & $61(98.4 \%)$ & $1(1.6 \%)$ & $61(98.4 \%)$ & $0(0.0 \%)$ & $1(1.6 \%)$ \\
\hline & Year 2 & $62(91.2 \%)$ & $1(1.5 \%)$ & $5(7.4 \%)$ & $68(100.0 \%)$ & $0(0.0 \%)$ & $66(97.1 \%)$ & $1(1.5 \%)$ & $1(1.5 \%)$ \\
\hline & Year 3 & 93 (86.1\%) & $1(0.9 \%)$ & $14(13.0 \%)$ & 107 (99.1\%) & $1(0.9 \%)$ & 107 (99.1\%) & $1(0.9 \%)$ & $0(0.0 \%)$ \\
\hline & Year 4 & $85(91.4 \%)$ & $1(1.1 \%)$ & $7(7.5 \%)$ & $62(98.9 \%)$ & $1(1.1 \%)$ & $93(100.0 \%)$ & $0(0.0 \%)$ & $0(0.0 \%)$ \\
\hline & Year 5 & $90(84.1 \%)$ & $3(2.8 \%)$ & $14(13.1 \%)$ & $106(99.1 \%)$ & $1(0.9 \%)$ & $105(98.1 \%)$ & $0(0.0 \%)$ & $2(1.9 \%)$ \\
\hline \multirow[t]{2}{*}{ Ethnic } & Malay & $382(88.0 \%)$ & $7(1.6 \%)$ & $45(10.4 \%)$ & $430(99.1 \%)$ & $4(0.9 \%)$ & $428(98.6 \%)$ & $2(0.5 \%)$ & $4(0.9 \%)$ \\
\hline & Non-Malay & $4(100.0 \%)$ & $0(0.0 \%)$ & $0(0.0 \%)$ & $4(100.0 \%)$ & $0(0.0 \%)$ & $4(100.0 \%)$ & $0(0.0 \%)$ & $0(0.0 \%)$ \\
\hline \multirow[t]{5}{*}{ Region } & Central & $95(84.1 \%)$ & $3(2.7 \%)$ & $15(13.3 \%)$ & $111(98.2 \%)$ & $2(1.8 \%)$ & $109(96.5 \%)$ & $2(1.8 \%)$ & $2(1.8 \%)$ \\
\hline & Southern & $69(90.8 \%)$ & $1(1.3 \%)$ & $6(7.9 \%)$ & 75 (98.7\%) & $1(1.3 \%)$ & $76(100.0 \%)$ & $0(0.0 \%)$ & $0(0.0 \%)$ \\
\hline & Northern & $61(84.7 \%)$ & $1(1.4 \%)$ & $10(13.9 \%)$ & $71(98.6 \%)$ & $1(1.4 \%)$ & $72(100.0 \%)$ & $0(0.0 \%)$ & $0(0.0 \%)$ \\
\hline & Eastern & $149(90.3 \%)$ & $2(1.2 \%)$ & $14(8.5 \%)$ & $165(100.0 \%)$ & $0(0.0 \%)$ & $163(98.8 \%)$ & $0(0.0 \%)$ & $2(1.2 \%)$ \\
\hline & $\begin{array}{l}\text { Labuan/ } \\
\text { Sabah/ } \\
\text { Sarawak }\end{array}$ & $11(100.0 \%)$ & $0(0.0 \%)$ & $0(0.0 \%)$ & $11(100.0 \%)$ & $0(0.0 \%)$ & $11(100.0 \%)$ & $0(0.0 \%)$ & $0(0.0 \%)$ \\
\hline \multirow[t]{2}{*}{ Marital status } & Married & $9(100.0 \%)$ & $0(0.0 \%)$ & $0(0.0 \%)$ & $9(100.0 \%)$ & $0(0.0 \%)$ & $9(100.0 \%)$ & $0(0.0 \%)$ & $0(0.0 \%)$ \\
\hline & $\begin{array}{l}\text { Non- } \\
\text { married }\end{array}$ & $377(87.9 \%)$ & $7(1.6 \%)$ & $45(10.5 \%)$ & $425(99.1 \%)$ & $4(0.9 \%)$ & $423(98.6 \%)$ & $2(0.5 \%)$ & $4(0.9 \%)$ \\
\hline \multirow{3}{*}{$\begin{array}{l}\text { Household } \\
\text { income }\end{array}$} & $\mathrm{T} 20$ & $144(88.9 \%)$ & $3(1.9 \%)$ & $15(9.3 \%)$ & $161(99.4 \%)$ & $1(0.6 \%)$ & $158(97.5 \%)$ & $2(1.2 \%)$ & $2(1.2 \%)$ \\
\hline & M40 & $126(88.1 \%)$ & $1(0.7 \%)$ & $16(11.2 \%)$ & $141(98.6 \%)$ & $2(1.4 \%)$ & $141(98.6 \%)$ & $0(0.0 \%)$ & $2(1.4 \%)$ \\
\hline & B40 & $111(87.4 \%)$ & $3(2.4 \%)$ & $13(10.2 \%)$ & $127(100.0 \%)$ & $0(0.0 \%)$ & $127(100.0 \%)$ & $0(0.0 \%)$ & $0(0.0 \%)$ \\
\hline $\begin{array}{l}\text { Knowledge } \\
\text { score }\end{array}$ & & $11.1(1.3)$ & $11.4(0.8)$ & $11.0(2.1)$ & $11.1(1.4)$ & $11.3(1.5)$ & $11.1(1.2)$ & $11.0(1.4)$ & $5.3(6.1)^{*}$ \\
\hline
\end{tabular}

$* \mathrm{P}<0.001$; All other associations are not significant.

students in India ${ }^{15}$ and Jordan. ${ }^{22}$ In contrast, studies conducted in low- and middle-income countries have reported poor or negative attitudes among students such as in Pakistan. ${ }^{23}$ Enforcing MCO by the Government of Malaysia and the academic programme may have contributed to the positive attitudes.

The result showed no significant association between gender and attitudes towards COVID- 19. However, a study from Pakistan reported that majority of the female students compared to male students showed positive attitudes. ${ }^{24}$ Our study showed that students who are unsure that our government is handling this pandemic very well had significantly lower knowledge scores than those who agreed. This result strengthened the conclusion from earlier study that higher level of knowledge is positively associated with higher confidence and positive attitude in health crisis. ${ }^{10,25}$

\section{Practices on COVID 19}

Our results indicated that $93 \%$ of the participants practiced preventive behaviour during the week of
MCO. This is in line with the practices followed by the Iranian medical students $(95 \%),{ }^{12}$ but higher than the medical students in Uganda (57\%). ${ }^{13}$ In accordance with the findings from Iran (99.6\%), ${ }^{12}$ the current study found that $90.9 \%$ of the students avoided crowded places. However, there is still a small group of participants who did not avoid crowded places.

With regard to wearing face mask when leaving home, the rate is higher among participants in this study $(97 \%)$ compared the counterparts in Jordan $(64.7 \%)^{26}$ and in Philippine (28\%). ${ }^{27}$ Yet a few proportions of the medical students in this study did not wear face mask. This may be due to the uncommon practices of wearing face masks in Malaysia, and unavailability of face masks in the market because of imbalance between sudden increase of global demand due to pandemic and limited supply.

Nine in every 10 students in this study practiced proper hand hygiene by frequently washing their hands and using hand sanitizer. This is similar with the study in Uttarakhand, India, where $92.7 \%$ of medical students 
practiced proper hand hygiene. ${ }^{15}$ Consistent with the results from the medical students in India, ${ }^{28} 8.4 \%$ of the medical students in IIUM did not practice correct hand hygiene. Hence, it is important to ensure that these students practice proper hand hygiene because they are the future health practitioners and educators to general population.

The study encountered a number of limitations. This study was susceptible to self-reporting bias which can particularly be seen in attitudes and practices segments of the study. Attitudes and practices are supposed to be measured accurately through observation, however, it is measured through self-reported questionnaires in this study. Therefore, socially desirable responses might be documented even though it was not practiced. This bias is reduced by ensuring the anonymity of students. As this study uses an online survey, underprivileged students who did not have good internet access might not participate in the study. Conjointly, students might search for information via internet, causing a chance of over reporting bias. Some important possible factors that might influence KAP were not studied. Lastly, this study cannot be generalized to the medical students of other universities in Malaysia.

\section{CONCLUSION}

Eight in every 10 students had correct knowledge and 9 in every 10 students showed optimistic attitudes and appropriate practices towards COVID-19. However, only $12 \%$ of the students answered correctly on all knowledge questions, few proportions had misconception on the symptoms and transmission of the disease, and $8-9 \%$ did not avoid going to the crowded places and practice hand hygiene during the period of MCO. In view of their future role as medical practitioners, the policy makers should intensify the appropriate health promotion activities to empower the medical students with adequate knowledge on all aspects of COVID-19, and to ensure proper practices following the standard operating procedure implemented by the government.

\section{CONFLICT OF INTEREST}

There is no conflict of interest for this paper.

\section{ACKNOWLEDGEMENT}

We would like to express our gratitude to all year 4 block 3 medical students of IIUM (2019-2020) for their assistance in data collection and a sincere thanks to all medical students of IIUM who participated in the study.

\section{REFERENCES}

1. World Health Organization. Timeline: WHO's COVID-19 response. In: World Health Organization Emergencies [online]. Available at: https://www.who.int/emergencies/diseases/novelcoronavirus-2019/interactive-timeline/\# event-71. Accessed August 3, 2020.

2. World Health Organization. Coronavirus. In: World Health Organization Health Topics [online]. Available at: https://www.who.int/health-topics/ coronavirus. Accessed August 3, 2020.

3. Zhong B, Luo W, Li H, Zhang Q, Liu X, Li W et al. Knowledge, attitudes, and practices towards COVID-19 among Chinese residents during the rapid rise period of the COVID-19 outbreak: a quick online cross-sectional survey. International Journal of Biological Sciences. 2020;16:1745-1752.

4. Shereen MA, Khan S, Kazmi A, Bashir N, Siddique R. COVID-19 infection: Origin, transmission, and characteristics of human coronaviruses. Journal of Advanced Research. 2020;24:91-98.

5. World Health Organization. Coronavirus disease (COVID-19) situation reports in Malaysia. In: World Health Organization Emergencies [online]. Available at: https://www.who.int/malaysia/ emergencies/coronavirus-disease-(covid-19)-inmalaysia/covid-19-situation-reports-in-malaysia. Accessed August 3, 2020.

6. Ministry of Health Malaysia. COVID-19 Malaysia. Available at: http:/ / covid-19.moh.gov.my. Accessed August 3, 2020.

7. Abdullah JM, Wan Ismail WFN, Mohamad I, et al. A Critical Appraisal of COVID-19 in Malaysia and Beyond. Malays J Med Sci. 2020;27:1-9.

8. Sadiq A, Muhammad S, Saleem, et al. How COVID -19 is Changing Behaviours of Population: A Study from Punjab. Biomedica. 2020;36:253-259.

9. Tao N. An analysis on reasons of SARS-induced psychological panic among students. Journal of Anhui Institute of Education. 2003; 21:78-9. 
10. Azlan AA, Hamzah MR, Sern TJ, Ayub SH, Mohamad E. Public knowledge, attitudes and practices towards COVID-19: A cross-sectional study in Malaysia. Plos One. 2020;15:1-15.

11. Ministry of Higher Education Malaysia. [Speech Text Press Release Ministry of Higher Education Reopening of Institute of Higher Education Campuses in Stages]. In: Ministry of Higher Education Media [online]. Available at: https:// www.mohe.gov.my/en/media-mohe/speech-text. Accessed August 3, 2020. [Malay].

12. Taghrir MH, Borazjani R, Shiraly R. COVID-19 and Iranian Medical Students; A Survey on Their Related-Knowledge, Preventive Behaviors and Risk Perception. Archives of Iranian Medicine. 2020 1;23:249-54.

13. Olum R, Kajjimu J, Kanyike AM, et al. Perspective of medical students on the COVID-19 pandemic: Survey of nine medical schools in Uganda. JMIR Public Health and Surveillance. 2020;6:e19847.

14. Department of Statistic Malaysia. Report of Household Income And Basic Amenities Survey 2016 [online]. Available at: https:// www.dosm.gov.my/v1/index.php?r=column/ cthemeByCat\&cat=120\&bul_id=RUZ5REwveU1r a1hGL21JWVIPRmU2Zz09\&menu_id=amVoWU 54UT10a21NWmdhMjFMMWcyZz09. Accessed September 30, 2020.

15. Maheshwari S, Gupta PK, Sinha R, Rawat P. Knowledge, attitudes, and practices towards coronavirus disease 2019 (COVID-19) among medical students: A cross-sectional study. Journal of Acute Disease. 2020;9:100.

16. Begum F. Knowledge, Attitudes, and Practices towards COVID-19 among B.Sc. Nursing Students in Selected Nursing Institution in Saudi Arabia during COVID-19 Outbreak: An Online Survey. Saudi Journal of Nursing and Health Care. 2020;3:194-198.

17. Modi PD, Nair G, Uppe A, Modi J, Tuppekar B, Gharpure AS, Langade D. COVID-19 awareness among healthcare students and professionals in Mumbai metropolitan region: a questionnaire-based survey. Cureus. 2020;12(4).

18. Wadood MA, Mamun A, Rafi MA, et al. Knowledge, attitudes, practices and perception regarding COVID-19 among students in Bangladesh: Survey in Rajshahi University. 2020.
19. Tadesse AW, Melese N, Eshetie S, Chane M, Ali A. Knowledge, Attitude, and Practice and Associated Factors towards COVID-19 among College Students in Amhara Region, Ethiopia; A CrossSectional Study. 2020.

20. Saefi M, Fauzi A, Kristiana E, et al. Survey data of COVID-19-related knowledge, attitude, and practices among indonesian undergraduate students. Data in Brief. 2020;31:105855.

21. Peng Y, Pei C, Zheng Y, et al. A cross-sectional survey of knowledge, attitude and practice associated with COVID-19 among undergraduate students in China. BMC Public Health.

2020;2:1292.

22. Khasawneh AI, Humeidan AA, Alsulaiman JW, et al. Medical Students and COVID-19: Knowledge, Attitudes, and Precautionary Measures. A Descriptive Study From Jordan. Frontiers in Public Health. 2020;8:253.

23. Ikhlaq A, Bint-e-Riaz H, Bashir I, Ijaz F. Awareness and Attitude of Undergraduate Medical Students towards 2019-novel Corona virus. Pak J Med Sci. 2020;36(COVID19-S4):COVID19-S32-S.

24. Salman M, Mustafa ZU, Asif N, et al. Knowledge, attitudes and preventive practices related to COVID-19: A cross-sectional study in two Pakistani university populations. Springer Link. 2020;36:319-325.

25. Shi Y, Wang J, Yang Y, et al. Knowledge and attitudes of medical staff in Chinese psychiatric hospitals regarding COVID-19. Brain, Behavior, \& Immunity-Health. 2020;29:100064.

26. Alzoubi H, Alnawaiseh N, Al-Mnayyis A, et al. COVID-19-knowledge, attitude and practice among medical and non-medical University Students in Jordan. J Pure Appl Microbiol. 2020;14:17-24.

27. Lau LL, Hung N, Go DJ, et al. Knowledge, attitudes and practices of COVID-19 among income-poor households in the Philippines: A cross -sectional study. J Glob Health 2020;10:011007.

28. Das D, Shenoy R, Mukherjee M, Unnikrishnan B, Rungta N. Awareness Among Undergraduate Students of Mangalore City Regarding Novel Coronavirus (COVID-19): A Questionnaire Study. Disaster Medicine and Public Health Preparedness. 2020;1-4. 